\section{Matemática financeira e Problemas de matemática financeira}

Por Walter de Francisco. São Paulo, Atlas, 1974. 197 e 160 p. respectivamente.

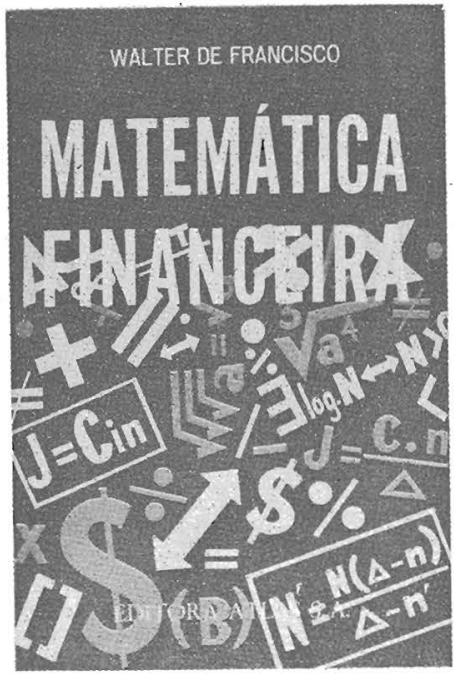

O livro, segundo a orelha da contracapa, destina-se a administradores e economistas em nível de cursos de administração e engenharia. Provavelmente o autor queria dizer "engenharia econômica", pois é duvidoso o sentido da "introdução matemática" dado ao livro de matemática financeira para curso de engenharia, onde se dedicam dois anos ao estudo de conceitos matemáticos superiores.

O volume referente aos problemas pode ser considerado sem complexidade, bem impresso e de interesse para o professor, aluno e autodidata. A editora prometeu um guia do mestre, o que deverá aumentar sua utilidade. No entanto, os problemas resolvidos no volume de teoria são suficientes para se adquirir uma sólida base de matemática financeira.

O volume que trata de teoria é bem elaborado, apresentando com clareza a matemática financeira, com as aplicações de fórmulas para os diversos problemas, por exemplo, as diferentes maneiras de se calcular descontos. $\mathrm{Na}$ breve introdução à engenharia econômica, à página $¥ 61$, e na apresentação de algumas previsões financeiras à página 177, o autor penetra muito pouco no vasto campo da análise de investimentos, mas com sucesso. $O$ autor mostra com êxito a utilidade da regressão nãolinear, questão esta normalmente ausente nos livros desse gênero. A extrapolação errada é evitada no caso de incerteza entre a fun: ção linear e não-linear.

Para o desenvolvimento da base e dos logaritmos neperianos, à página 60 , o autor não tece nenhuma consideração anterior, supondo um conhecimento matemático maior que o do capítulo inicial, por parte do leitor.

A falta de tabelas financeiras completas de juros compostos, descontos, séries, etc. é justificada pela possibilidade da aplicação de interpolação. No entanto, editar um livro no Brasil com juros de 3 a $12 \%$ é eternizar uma mentira das agendas de bolso com a $\mathrm{Ta}$ bela Price: ninguém aqui escapa aos 20, 25 e $30 \%$ anuais e o $n$ (períodos) dado nas tabuelas só vai até 25 , impedindo assim o uso do período como sendo o de capitalização mensal por mais de dois anos. Por outro lado, ele só começa com $3 \%$, mostrando que realmente o juro está limitado. Tudo isto diminui o valor dessa edição.

A nova edição, que, espero, o livro merecerá em breve, deverá ter tabelas completas, hoje tão fáceis de serem calculadas por computadores. Também na nova edição não poderá faltar uma bibliografia mais abrangente; por exemplo, Bónini tem um livro de matemática financeira, e o livro de Grant e Ireson, Principles of engineering economy, não pode ser esquecido.

A Editora Atlas, de certa maneira, faz concorrência a si mesma e completa a sua linha com este livro, pois publicou há pouco a Análise financeira de alternativas de investimento, de Raymond Mayer. Por sinal, Mayer é menos preciso nos conceitos (como já tive ocasião de escrever) que na metodologia da engenharia econômica, no que se refere às deduções de fórmulas que caracterizam tanto Francisco quanto Bonini. Pergunta-se se essas deduções são úteis. No decorrer dos anos, tendo lecionado para muitos cursos sucessivamente, mudei muito minha idéia original, aceitando novas fórmulas, dedicando mais tempo ao aperfeiçoamento da interpretação dos resultadós e das supa sições e realizando exames com os livros abertos. Francisco é especialmente útil para o autodidata, posto que tabelas mais completas o tornariam mais útil ao ensino em geral.

O leitor irá reparar no capítulo sobre depreciação, à página 153, uma grave falha de esclarecimento: no Brasil, somente são permissíveis métodos que dêem quantia depreciada igual ou menor que - método linear.. Só assim são aceitáveis para a contabilidade fiscal das empresas. Não se fala evidentemente da contabilidade industrial. Indubitavelmente, uma vez feito o cálculo, os alunos acreditam que os métodos são "legais", pois é o livro que os apresenta.

Além dos capítulos já enunciados: Complementos de matemática; Depreciação; Engenharia econômica; e Previsões financeiras, 0 livro apresenta mais os seguintes: Juros e descontos simples; Juros compostos; Desconto composto; Rendas; e Empréstimos.

Todos eles são interessantes e explícitos. Apenas para comparação: o livro de Mayer, Análise financeira de alternativas de investimento traz os seguintes capítulos: Introdução à análise de projetos; Custos relevantes - depreciação, juros; Fatores de juros compostos; Métodos do custo anual uniforme; Método do valor atual; Método da taxa de retorno; Problemas de alternativas múltiplas; Considerações fiscais $(1 \mathrm{~m}$ posto sobre a Renda).

Como os capítulos de Custos relevantes e Fatores de juros compostos tomam mais da metade do livro, nota-se, ao mesmo tempo, a diferença e a semelhança entre livros de matemática financeira e engenharia econômica, além da duplicação parcial de esforços da Editora Atlas.

Assim, os dois volumes, bons, se completam, de um lado, mas apresentam lacunas em certos assuntos. No todo, recomendamos - livro para escolas superiores de administração e possivelmente de técnica de administração de nível secundário.

Kurt E. Weil 